\title{
Alternative methods of delivering concrete and mortar mixes to low-rise construction projects
}

\author{
Boris Zhadanovsky and Vladimir Bazanov* \\ Moscow State University of Civil Engineering, 129337, Moscow, Russia
}

\begin{abstract}
Concrete mixes are usually delivered to construction projects with the help of special vehicles. Depending on its fluidity, cement setting rate, temperature and relative humidity of carriage conditions, as well as a distance and road condition, transportation of a concrete mix may be done in concrete mixer trucks and ready-mix delivery trucks, also in buckets and hoppers mounted on vehicles (bucket trucks). At the same time, it is necessary to reduce the number of transship operations as much as possible and, wherever practicable, unload a mix directly into the structure to be concreted. Each method of transportation has its rational areas of application. For low-rise construction characterized by small volumes, scattered construction sites, insufficient coverage by a good-quality road system, and a long distance from concrete factories, it is expedient to use alternative, non-dedicated to concrete mix transportation, types of vehicles equipped with their own lifting devices. The issues of application of dropside lorries with crane manipulators and gantry hopper trucks for transportation of ready-mix buckets are discussed. The technical characteristics of general purpose vehicles and lifting equipment are described. Recommendations concerning fitting of various types of vehicles with portable hoppers are given.
\end{abstract}

\section{Introduction}

According to items 9.1 and 9.2 of GOST 7473-2010, "concrete mixes are delivered to the user by special types of vehicles designed for concrete mix carriage. As agreed between the manufacturer and user, it is allowed to deliver hard concrete mixes by dumping trucks. The methods of concrete mix transportation applied must preclude ingress of precipitation therein, impairment of homogeneity, and loss of cement mortar."

Improvement of the transport process of concrete mix delivery attracts constant attention.

Depending on its initial fluidity, the setting rate of cement used, distance, and temperature and relative humidity of carriage conditions, as well as the condition of roads used, different vehicles can be utilized for concrete mix transportation: concrete mixer trucks, ready-mix delivery trucks, drop-side lorries $[1,2,3]$. The choice of the main means

\footnotetext{
*Corresponding author: bazanov_kim@mail.ru
} 
of concrete mix delivery depends on the area of their rational use and is determined by their coverage limits and concrete mix fluidity [4].

In work $[5,6,7]$ discussed options of building simulation and process models for structured description of the technology of concrete mix transportation by vehicles at the level of production processes.

General issues of usage and development of concrete placing hardware and the directions of their development are discussed in the paper [8].

For cast-in-place concrete frame construction, the issues of concrete job mechanization are connected with selection of different options $[9,10]$.

Chulkova, Sankova, Kuznetsov [11] developed a model for automated formation of packages of machines and mechanisms for the production of concrete jobs. With the help of this model, it is possible to assess the efficacy of the choice of machines and mechanisms for concrete mix production, transportation, feeding, spreading, and compaction. The option selection methodology was also discussed.

Golovchenko [12] analyzed the methods of concrete mix delivery and feeding in the environment of high ambient air temperatures. The rational capacity of concrete mixer trucks depending on the distance from CBP to the project and concrete mix feeding technique was selected..

The organizational and process solutions of concrete mix transportation to the site of structural concreting of high-rise buildings and the technical and economic evaluation of the organizational and process flow charts of residential development by market indices are given in the papers $[13,14]$.

In the studies reviewed, concrete mixer truck and ready-mix delivery trucks are the main transport means applied for concrete mix delivery to a project.

Utilization of the organizational and process flow chart for transportation of concrete mixes in non-rotational buckets (hoppers) using trucks equipped with crane manipulators allows using the main crane highly efficiently thanks to freeing it from auxiliary handling operations and speeding up concreting operations thanks to production of works following a precomputed schedule of concrete mix delivery to the construction site [15].

Analysis of the development of cast-in-place low-rise construction and its prospects shows that cast-in-place and precast house-building experiences furtherance and becomes the predominant method in the general structure of low-rise construction complex $[16,17]$.

The low-rise construction conditions often imply small scope of work, scattered construction sites, insufficient coverage by a good-quality road system, as well as remoteness from central concrete mixing stations [18]. Delivery of a concrete mix by a concrete mixer truck becomes too costly because of additional transportation expenses and requires a fixed schedule of mix delivery to the project. Arranging a mobile concrete mixing station at a short distance from the construction site becomes preferable. In this instance, concrete mix can be delivered by ready-mix delivery trucks (which will require concrete mix transshipment into buckets following the 'crane-bucket' scheme), in buckets arranged in the truck body, or by special trucks - bucket trucks. Bucket truck is designed for transporting ready mixes in separate special buckets that are put on and off the bucket truck frame with the help of a crane and are left, together with the mix in a bucket, on the construction project for future use. With the help of a bucket truck, one can deliver small portions of a mix to any point on the construction site. The speed of transportation by bucket trucks by roads with a hard surface is up to $25 \mathrm{~km} / \mathrm{hr}$., with soft earth surface - up to $15 \mathrm{~km} / \mathrm{hr}$. The maximal technologically allowable distance of concrete mix transportation at an ambient air temperature between \pm 20 and $+30{ }^{\circ} \mathrm{C}$ is 5 to $2 \mathrm{~km}$ depending on the mix fluidity [19]. 


\section{Materials and Methods}

At a construction site, empty buckets are unloaded from and loaded back onto vehicles by an additional crane while the main crane is used to feed a concrete mix to the point of placement. For transportation of a concrete mix and mortars in buckets, it is suggested to use vehicles not specifically intended for concrete mix carriage, which are equipped with crane manipulators (drop-side lorries with crane manipulators) and frame (gantry) hoists for container carriage. Carriage in buckets eliminates additional transshipment of a concrete mix on site - the mix is fed to the point of placement by a crane. Availability on a vehicle of its own lifting device such as a crane manipulator or a gantry hoist allows unloading the vehicle and load empty buckets back thereon without involving either the main or additional crane. In this way, the production of works is accelerated and the costs are reduced.

To clarify feasibility of usage of alternative general-purpose vehicles, the currently available fleet of domestic and imported container trucks, the dimensions and technical characteristics of vehicles and lifting devices have been analyzed.

\section{Results}

The requirements to portable hoppers (buckets) having a capacity of up to $2 \mathrm{~m}^{3}$, which are used in construction for transportation of a concrete mix by cranes to the place of structural concreting operations, are determined by national standard GOST 21807-76 [20]. Based on their structural design, hoppers are classified into two types: $\Pi$ - rotational; $\mathrm{H}-$ nonrotational (fig. 1).

The capacity of rotational hoppers is as follows: $0.5,1.0,1.6$, and $2.0 \mathrm{~m}^{3}$; that of nonrotational -0.5 and $1.0 \mathrm{~m}^{3}$. The dimensions and weight of hoppers are given in table 1 . The concrete mix volume-weight is assumed equal to $2400 \mathrm{~kg} / \mathrm{m}^{3}$.

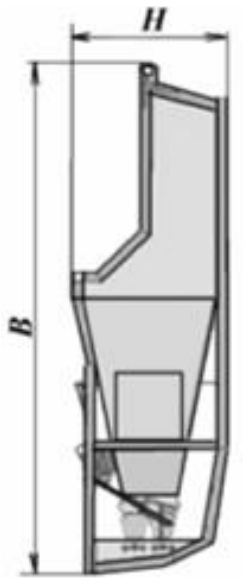

a)

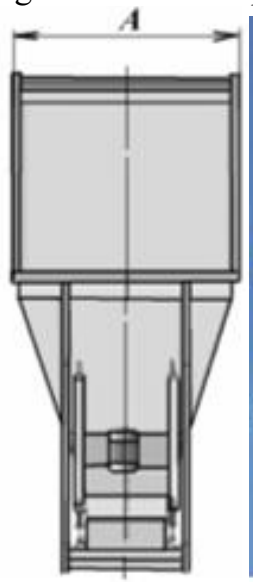

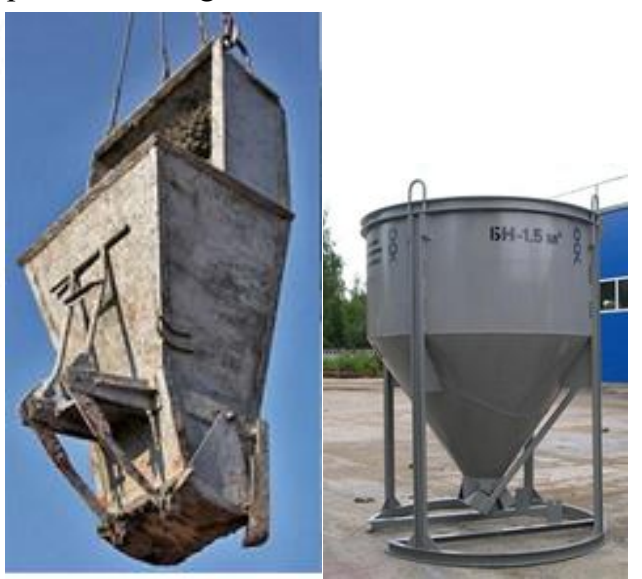

b)

Fig. 1. Portable concrete mix hoppers (buckets): $\mathrm{a}$ - rotational; b - non-rotational

It follows from the above table that the maximal lifting capacity of a crane manipulator or a gantry hoist should be not more than $3000 \mathrm{~kg}$ for $1.0 \mathrm{~m}^{3}$ hoppers and not more than $5900 \mathrm{~kg}$ for $2.0 \mathrm{~m}^{3}$ hoppers

The dimensions of hoppers make it possible to accommodate, in a vehicle of a standard size (width $-2.5 \mathrm{~m}$, length $-4.5-6 \mathrm{~m}$ ), up to 3 non-rotational hoppers, each having a capacity of $1.0 \mathrm{~m}^{3}$, or one rotational hopper of any capacity between 0.5 and $2.0 \mathrm{~m}^{3}$. 
Table1. Weight and dimensions of portable rotational and non-rotational concrete mix hoppers

\begin{tabular}{cccccc}
\hline $\begin{array}{c}\text { Descrip- } \\
\text { tion }\end{array}$ & $\begin{array}{c}\text { Desig- } \\
\text { nation }\end{array}$ & $\begin{array}{c}\text { Capacity, } \\
\mathrm{m}^{3}\end{array}$ & $\begin{array}{c}\text { Dimensions } \\
\text { (length*width/ } \\
\text { diameter), mm }\end{array}$ & $\begin{array}{c}\text { Empty } \\
\text { Weight, kg }\end{array}$ & $\begin{array}{c}\text { Total } \\
\text { Weight } \\
\text { with } \\
\text { Concrete } \\
\text { Mix, kg }\end{array}$ \\
\hline $\begin{array}{c}\text { Rotation } \\
\text { al } \\
\text { hopper }\end{array}$ & RH-0.5 & 0.5 & $2850 * 1000$ & 325 & 1575 \\
& RH-1.0 & 1.0 & $330 * 1500$ & 500 & 3000 \\
\hline $\begin{array}{c}\text { Non- } \\
\text { rotationa } \\
1 \text { hopper }\end{array}$ & NH-0.5 & 2.0 & $3690 * 2020$ & 900 & 5900 \\
\hline
\end{tabular}

\section{Discussion}

Concrete mix transportation by road is carried out in dumping trucks, ready-mix delivery trucks, concrete mixer trucks, and in hoppers or buckets placed in the bodies of drop-side lorries.

Special ready-mix delivery trucks with a synclinal (trough-shaped) body without a tailgate are used in case of mass transportation of a concrete mix that is unloaded directly into the unit being concreted (a foundation) or transshipped into devices feeding a concrete mix to the point of placement (a hopper of a concrete pump or a concrete spreader, a bucket).

For low-rise construction with its relatively small concreting volumes, the concrete mixer truck-concrete pump process flow is inefficient, so the crane-bucket process flows seem more preferable. Buckets with a concrete mix can be delivered to a construction site by vehicles not specifically designed for concrete mix transportation: by hopper trucks equipped with a gantry hoist and by trucks equipped with crane manipulators.

Gantry lift trucks belong to the category of vehicles with interchangeable bodies. In this country, the first selfloader-hopper truck ZIL-MMZ-4952 with an interchangeable body was developed in 1985 at the Mytishchi Machine-Building Factory on the basis of ZIL495710 chassis. That truck could carry any cargo - mortars, bricks, containers, metal. A removable chain-suspended metal body (container), was removed or loaded with the help of hydraulically driven rocker levels. Interchangeable containers of an open type can have a different capacity and purpose. The container is removed from the frame by a gantry and placed onto an even ground for loading. At the end of filling, the truck returns and lifts the filled container onto the truck. All operations of loading and unloading the content are performed by the driver, the truck stability being provided by outriggers. It takes about a minute and a half for the gantry mechanism to lift a container. Special equipment of such truck usually includes: a container, a frame, a gantry, outriggers, and a hydraulic system. In some models, a special platform for transportation of small-sized automotive and construction equipment, which largely extends the truck capabilities.

At present, trucks of this class handle open hoppers designed for collection of bulky domestic and construction debris, therefore in Russia they are frequently referred to as hopper trucks or hopper garbage-removal trucks (fig. 2). Frame (gantry) hopper trucks are designed for the transportation of hopper having a capacity of up to $8 \mathrm{~m}^{3}$. These are the most common garbage-removal trucks engaged in removal of bulky domestic garbage. The body width of a hopper truck is a bit narrower than the transportation dimensions due to gantry arrows fitted on its sizes. To preclude container displacement during transportation, on the 
garbage-removal truck platform there are special supports adjustable to different sizes of containers. The gantry arrows of a hopper truck may be both single- and two-section. In the latter case, a hopper truck may take its body off onto a surface above the bearing plane of the truck.
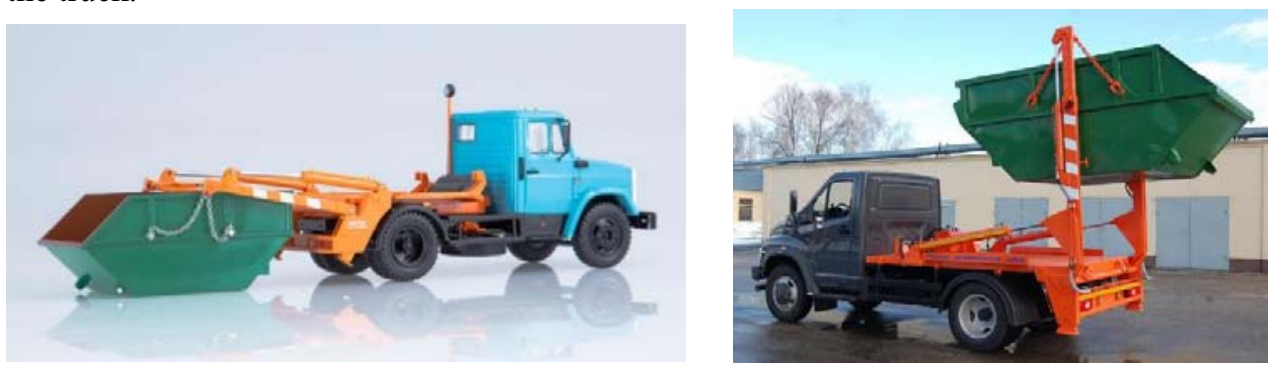

Fig. 2.Gantry hopper garbage-removal truck

Gantry garbage-removal truck are manufactured all over the world by a great number of companies including on the basis of Volvo, Scania, Daf, Man, Mercedes-Benz, Iveco, Isuzu chassis [21]. In Russia, such vehicles are made by JSC Arzamas Utility Machine-Building Factory (AZKM), JSC Ryazhskiy Motor Vehicle Repair Factory (RARZ), JSC Mzensk Utility Machine-Building Factory (MZKM), Utility Machine-Building Factory VyshniyVolochyok Machine-Building Factory, a branch of OOO Metrowagonmash (VMSZ), and many more [22]. The technical characteristics of the main models of domestic hopper trucks are given in table 2.

Table 2. Technical characteristics of hopper trucks

\begin{tabular}{cccc}
\hline Model & Base Chassis & GantryCapacity, kg & Manufacturer \\
\hline MK-1412-13 & GAZ-C41R11 (4x2) & 2545 & RARZ \\
KO-450-11 & MAZ-4371N2 (4x2) & 3745 & MZKM \\
KO-450-08 & MAZ-4381C0 (4x2) & 5545 & MZKM \\
KO-450-10 & MAZ-5550C3 (4x2) & 7000 & MZKM \\
MK-4512-04 & KAMAZ-43255-R4 (4×2) & 7180 & RARZ \\
MK-3512-02 & MAZ-5550B2 (euro-4) (4x2) & 9595 & RARZ \\
\hline
\end{tabular}

Foreign hopper truck models have similar characteristics. Compact and powerful hopper trucks are indispensable on construction sites where it is often difficult to find a suitable place and access drives to arrange a permanent loading ground.

Another type of general purpose vehicles that would be suitable for transportation of concrete buckets are trucks equipped with crane manipulators. A crane manipulator is a compact system for loading and unloading various equipment and other heavy cargo. A crane manipulator is mounted onto drop-side lorries behind the cabin or in the rear part of the cargo platform (fig. 3).

a)
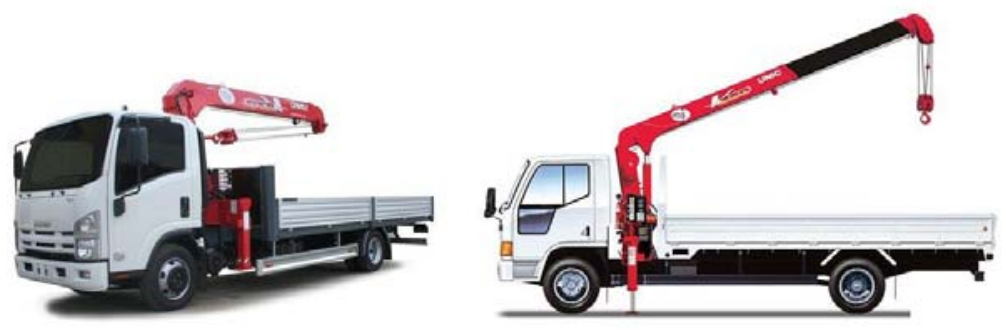
b)
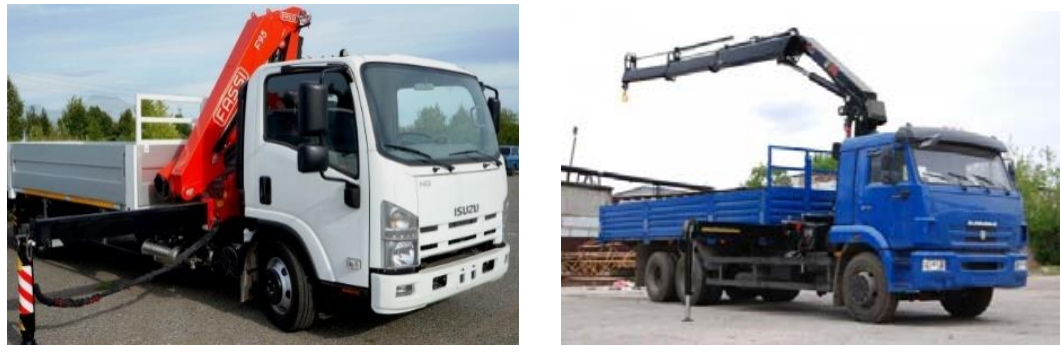

Fig. 3. A lorry with a crane manipulator: $a$ - L-shaped crane manipulator; $b$ - Z-shaped crane manipulator

A lorry with a crane manipulator replaces several types of equipment at once (fig. 4): it delivers cargos, unloads them and places where necessary, reducing the time and financial expenses during production of work. Today, it is more rational to move cargos weighting up to 30 tons with the help of a crane manipulator, more so as their price is several times lower than that of a motor crane [23].

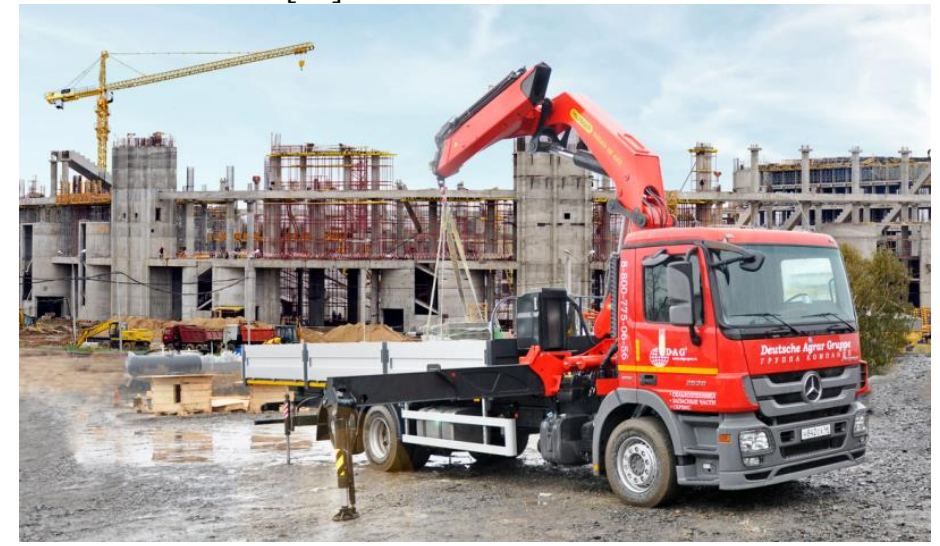

Fig. 4. A lorry with a crane manipulator at a construction site (www.inman.ru)

Lorries equipped with a crane manipulator are used as general-purpose loader fully replacing a motor crane during roadwork, maintenance works, pipe-laying operations, landscaping, in low-rise construction, and on constraint sites where there is insufficient place for regular motor crane operation.

The crane manipulator is a lifting device comprising arrow operational equipment, load gripping members, a control system, and a support frame. Equipment of such kind can be installed on motor chassis designed and assembled from scratch, or refurbished on the base of regular motor cars. Crane manipulators are classified based on the load moment: the relation of carrying capacity to arrow outreach. The load moment is measured in tons per meter, so, based on this parameter, crane manipulators are classified into light - up to 10 tm, medium - up to $22 \mathrm{tm}$, and heavy - over $22 \mathrm{tm}$.

Crane manipulators can be rope or hydraulically driven. The first ones are good to handle loads situated below the axis of special equipment position or behind some obstacles. Their arrow configuration allows vertical lowering of loads only. The arrow is above the lorry body in or opposite to the direction of lorry motion (the L-shaped hydraulic manipulator design). The latter are smaller in size (thanks to their Z-shaped design), more general, multifunctional, and maneuverable. In the stowed position, the arrow is located in the transversal plane of the lorry behind the cabin. They are more suitable for confined space operations [24]. 
Internationally, the number of crane manipulator manufacturers is quite large: Palfinger, Unic, KESLA-F (former Foresteri), Tadano, Soosan, HIAB, Loglift, Dongyang, Kanglim, Jonsered, Tico, Fiskars, CS Machinery, etc. Crane manipulators can be mounted almost on any motor car (KamAZ, Ural, ZIL, MAZ, GAZ, Hyundai, Isuzu, Volvo, Renault, MAN, and so on), depending on the industry of their application. It should be noted that installation of crane manipulators (including of foreign make) onto the chassis of drop-side lorries, semitrailers, towing motor vehicles is performed by Russian manufacturing factories. Many companies render all-inclusive services comprising selection of the necessary crane manipulator, installation of crane manipulator onto the motor vehicle, and completion of permits required for operation of a car-mounted crane manipulator.

A great number of vehicles equipped with a crane manipulator are in operation in Russia.

To help finding whether it is possible to use a vehicle with a crane manipulator for carriage of hoppers (buckets) with a concrete mix, table 3 contains technical characteristics of some models of lorries.

Table 3. Technical characteristics of vehicles equipped with a crane manipulator

\begin{tabular}{|c|c|c|c|c|}
\hline Base Chassis & $\begin{array}{c}\text { Hoisting } \\
\text { Mechanism (Crane } \\
\text { Manipulator) }\end{array}$ & $\begin{array}{c}\text { Crane } \\
\text { Manipulator } \\
\text { Carrying } \\
\text { Capacity, } \\
\text { kg }\end{array}$ & $\begin{array}{c}\text { Body Size } \\
\text { (length*width), } \\
\mathrm{mm}\end{array}$ & $\begin{array}{c}\text { Carrying } \\
\text { Capacity of } \\
\text { Vehicle, } \\
\text { kg }\end{array}$ \\
\hline $\begin{array}{c}\text { Hyundai HD } \\
78(4 \times 2)\end{array}$ & Soosan SCS 334 & $2.0 \mathrm{~m} / 3200$ & $6200 * 2500$ & 5000 \\
\hline $\begin{array}{c}\text { FAW TigerV } \\
(4 \times 2)\end{array}$ & UNIC URV 374 & $\begin{array}{c}2.6 \mathrm{~m} / 3200 \\
9.8 \mathrm{~m} / 480\end{array}$ & $6200 * 2300$ & 4700 \\
\hline $\begin{array}{l}\text { KAMAZ- } \\
65117(6 x 4)\end{array}$ & Kanglim $1256 \mathrm{G}-2$ & $\begin{array}{l}2.0 \mathrm{~m} / 7000 \\
4.0 \mathrm{~m} / 4000\end{array}$ & $6112 * 2470$ & 12600 \\
\hline $\begin{array}{l}\text { KAMAZ- } \\
65115(6 x 4)\end{array}$ & ATLAS $145 \mathrm{CS}$ & $\begin{array}{l}4.2 \mathrm{~m} / 3470 \\
6,1 \mathrm{~m} / 2380\end{array}$ & $6112 * 2470$ & 11000 \\
\hline $\begin{array}{c}\text { KAMAZ } \\
43118(6 x 6)\end{array}$ & Soosan SCS 513 & $\begin{array}{c}3.2 \mathrm{~m} / 3400 \\
8 . \mathrm{m} / 1200\end{array}$ & $5500 * 2300$ & 10000 \\
\hline
\end{tabular}

The possibility of using vehicles with a crane manipulator depends on the body size and carrying capacity of the crane manipulator. Having the regular body width of $2.5 \mathrm{~m}$ and length of 5.2-6.8m, a vehicle can accommodate several rotational hoppers at once (up to 4 $0.5 \mathrm{~m}^{3}$ hoppers; $21.0 \mathrm{~m}^{3}$ hoppers; one $2.0 \mathrm{~m}^{3}$ hopper plus one $0.5 \mathrm{~m}^{3}$ hopper), or 1 to 4 nonrotational hoppers depending on the carrying capacity of the vehicle.

Crane manipulators are often mounted onto four-wheel drive off-road cars, which allows using them on construction sites in hard-to-reach places, in places with an undeveloped or half-constructed road system.

\section{Conclusions}

Application of general-purpose vehicles equipped with their own lifting devices allows their highly efficient usage during the whole construction period not only for delivery of materials and equipment but for such special activity as transportation of a concrete mix to a project, too.

Today, garbage-removal trucks are among the most demanded types of utility equipment, while garbage-removal trucks with a removable hopper and a gantry loading mechanism are widely used in Russia thanks to their simplicity and universal nature. 
Multi-functionality and general capabilities of vehicles equipped with crane manipulators and hydraulic manipulators, together with high cost-efficiency of their operation, make them continuously highly demanded by users.

The versatility of technical characteristics of such kind of motor transport, their affordability and availability, as well as relatively low operational expenses make them desirable in a low-rise construction setting for transportation of a concrete mix in portable hoppers (buckets).

It should be taken into account that in any case, the types of transport means, the methods and modes of concrete mix delivery are to be agreed between the manufacture, customer and shipping company based on regulatory documents in force and actual data taking into consideration the mix composition, climatic, organizational and road conditions.

\section{References}

1. H. Bauer, Baubetrieb 3., vollst. neu bearb. Aufl.( Springer-Verlag, Berlin, 2007).

2. H. König, MaschienenimBaubetrieb: Grundlagen und Anwendung 2., akt. u. erw. Aufl., (Vieweg+Teubner Verlag, Wiesbaden, 2008).

3. S.G. Osmanov Bulletin of Civil Engineers 2 (67) 128-134 (2018).

4. S.G. Osmanov and A.L.Zholobov, Inzhenernyj vestnik Dona 1 (15) 315-319 (2011).

5. E. Kozniewski and Z. Orlowski, Concrete mix transportation modeling Journal of civil engineering and management, IX (I) 52-58(2003)

6. I.A. Bashmakov and A.V. Ostroukh, Automation and Control in Technical Systems (2013). https://doi.org/10.12731/2306-1561-2013-4-14

7. A.V. Ostroukh et al., Journal of Transportation Technologies 4 157-163 (2014). http://dx.doi.org/10.4236/jtts.2014.42016

8. P.V. Bol'shakova, Vestnik nauki i obrazovaniya, 7 (9) (2015) URL: https://cyberleninka.ru/article/n/ratsionalnye-napravleniya-razvitiyabetonoukladochnogo-kompleksa (in Russia)

9. K.S.Elliot and Z.A. Hamid, Modernisation, mechanisation and industrialisation of concrete structures (Wiley-Blackwell, Chichester, 2017).

10. S.G. Osmanov et al., Inzhenernyj vestnik Dona (2019). Ivdon.ru/ru/magazine/archive/n1y2019/5507 11 pp (in Russia)

11. I.L. Chulkova et al., ONV, 1 (64) (2008). URL: https://cyberleninka.ru/article/n/avtomatizirovannoe-formirovanie-komplektov-mashini-mehanizmov-dlya-proizvodstva-betonnyh-rabot

12. I.V.Golovchenko, Vestniknauki i obrazovaniya Severo-Zapada Rossii 2 (4) (2016).

13. L.M. Kolchedancev, and S.V. Volkov, Zhilishchnoe Stroitel'stvo 11(2015). URL: https://cyberleninka.ru/article/n/organizatsionno-tehnologicheskie-resheniya-potransportirovaniyu-betonnoy-smesi-k-mestu-betonirovaniya-konstruktsiy-vysotnyhzdaniy (in Russia)

14. S. V. Volkov and L. V.Volkova, Vestnik grazhdanskih inzhenerov, 1 (42) 6673(2014).

15. S. A.Mamochkin et al, Scientific Review 20 103-106(2015).

16. M. Y. Drebezgova et al., Vestnik BGTU imeni V.G. Shuhova 9 28-35 (2016). URL: https://cyberleninka.ru/article/n/analiz-i-perspektivy-razvitiya-monolitnogomaloetazhnogo-stroitelstva (in Russia) 
17. G. P. Sakharov and V.P. Strelbitskiy, Stroitel'nye materialy, oborudovanie, tekhnologii XXI 5 (160) 22-27(2012).

18. S. K. Hadadov and S.N. Shulzhenko, Moscow economic journal 12 808-815 (2019). URL: $\quad$ https://cyberleninka.ru/article/n/nekotorye-napravleniya-razvitiyamaloetazhnogo-monolitnogo-stroitelstva-v-sovremennyh-usloviyah

19. CNIIOMTP, Rekomendacii po dostavke betonnyh smesej avtotransportnymi sredstvami (Strojizdat, Moscow, 1988).

20. GOST 21807-76 Concrete mixture conveying buckets to 2 cub $m$ volume. General specifications (Standartinform, Moscow, 1976).

21. D. Vishnevskij, Osnovnye Sredstva, 11 (2015). https://os1.ru/article/4110-obzorportalnyh-konteynernyh-bunkerovozov-kakie-oni-gorodskie-musorovozy(in Russia)

22. V. Novosyolov, CTT Digest 6 26-32(2019)

23. S. Protasov, Osnovnye sredstva 6 (2010). https://os1.ru/article/6862-obzorrossiyskogo-rynka-kranov-manipulyatorov-komu-nujny-eti-kmu(in Russia)

24. D. Vishnevskij, Osnovnye sredstva, 12 (2019). https://os1.ru/article/24493-obzorkranovo-manipulyatornyh-ustanovok-universalniy-gruzchik(in Russia) 